\title{
Tax Competition in the European Union
}

\section{Article by an MPIfG researcher}

Vivek H. Dehejia, Philipp Genschel: Tax Competition in the European Union. In: Politics and Society 27(3), $403-430$ (1999).

Sage Publications

The original publication is available at the publisher's web site: http://dx.doi.org/10.1177/0032329299027003005

\section{VIVEK H. DEHEJIA \\ PHILIPP GENSCHEL}

\section{TAX COMPETITION AND ECONOMIC INTEGRATION}

"Governments need money. Modern governments need lots of money."1 Collecting this money is a tricky problem because nobody particularly likes to pay taxes. As the level of taxation reaches 30,40 , or even 50 percent in contemporary welfare states, the premium on tax avoidance and tax evasion rises. At the same time, the costs of doing so go down. The growing integration of the world's economies, the progress in trade liberalization and capital decontrol, and the rapid innovations in communication and transport technologies have made it easier to move goods, services, capital, and jobs across national borders and, consequently, more difficult to subject them to national taxes. Taxpayers can, in many cases, avoid high domestic taxes by shifting the tax base to a lower tax country. Exit has become a viable option and a credible implicit threat.

Governments may exploit this situation by undercutting the taxes of their neighbors. Tax-sensitive capital is lured away from foreign markets and improves domestic growth rates, employment figures, and fiscal revenues. Yet, what happens if other countries lower their taxes as well? After all, there is no obvious reason why any country should hold firm and let itself be victimized. Many economists argue that the competition for a mobile tax base will lead to a fiscally ruinous "race to the bottom," where the competing states interactively cut their taxes on

A preliminary version of this paper was presented at the GAAC workshop, "The Political Economy of European Integration," Bremen, Germany, August 1996, and a more recent version at the University of Chicago, May 1998. The authors thank David Carment, James Fearon, Mark Hallerberg, Anton Hemerijck, Thomas König, David Long, Susanne Lütz, Philip Manow, Thomas Plümper, David Pollock, Claudio Radaelli, Fritz Scharpf, Heiner Schulz, Hans-Werner Sinn, Ducan Snidal, Daniel Verdier, Raymund Werle, Michael Zürn, and the editors of this journal. Funding from the GAAC is gratefully acknowledged.

POLITICS \& SOCIETY, Vol. 27 No. 3, September 1999 403-430

(C) 1999 Sage Publications, Inc. 
capital and other mobile factors to ever lower levels, with potentially disastrous effects for public goods provision and income redistribution. As Bruno Frey warns, "In equilibrium, the tax rate on capital in each state will be driven to zero." Political scientists conclude that tax competition resembles a "standard prisoners" dilemma."3

The prisoners' dilemma is endemic to international politics. It complicates cooperation but does not make cooperation completely impossible. Repeated interaction and the long shadow of the future can mitigate the risk of defection and often enable actors to capture the benefits of cooperation. Institutions may further reduce the incentive to cheat by facilitating the monitoring of behavior and the punishment of defectors. Given long time horizons and effective institutions, states are reluctant to free-ride for fear of retaliation and loss of reputation. ${ }^{4}$ Numerous examples of successful international regimes in policy fields as diverse as trade, money, or the environment illustrate the point.

In tax policy, however, international cooperation is conspicuously absent. Tax experts occasionally call for a sort of GATT-type agreement on common rules for tax policy, ${ }^{5}$ and various international fora, including the IMF, the OECD, and the G-7, have discussed at one time or another the possibility of multilateral agreement to stop tax competition but, as yet, to little avail. Even in the European Union, where the economic integration is deeper and the record of successful cooperation better than anywhere else in the world, attempts to regulate tax competition collectively have failed quite regularly. The European Commission asserts that the need for Community action is large, but the Council of Ministers balks. ${ }^{6}$ Tax competition, it seems, is a particularly intractable problem for international cooperation. The purpose of this paper is to explore this puzzle: why does collective action so persistently fail in tax competition?

One possible answer would be to argue that the prisoners' dilemma problem is more pronounced in tax policy than in other policy fields. One might speculate, for example, that tax cooperation ${ }^{7}$ involves particularly severe problems of monitoring, enforcement, and incomplete contracting, which make it all but impossible to provide potential cooperators with sufficient safeguards against defection. However, it is not obvious why it should be more difficult to stabilize and maintain cooperation in taxation than, for example, in money or trade. Interviews with finance ministry officials show that they usually have a very clear picture of what is going on in other countries' tax policy domains. Monitoring is not an insurmountable obstacle. Enforcement and unforeseen contingencies may pose more serious problems, but again, it is not obvious why these problems should be of an entirely different magnitude than in trade or money. Given the stringency of EC law, the European Community, at least, should be able to deal with them. ${ }^{8}$ The Community's legal system has enabled the member states to tackle the "series of prisoners' dilemma games" ${ }^{\prime \prime}$ involved in the creation of the single market. Why 
should it not also enable them to master the prisoners' dilemma inherent in tax competition?

In this paper, we develop an alternative explanation. Taking our clue from Kenneth Oye's injunction, "When you observe conflict, think Deadlock-the absence of mutual interest-before puzzling over why a mutual interest was not realized, ${ }^{10}$ we argue that the prisoners' dilemma is a misleading metaphor for tax competition because it suggests that all competing states suffer from competition and therefore share a mutual interest in tax cooperation. But this is not generally valid. Small states can actually gain from tax competition and may be reluctant to support cooperation. As we will show, this distributive conflict, rather than the defection problem, is at the root of the continuous failure to achieve tax cooperation in the European Union.

As a first step, we develop a simple model, which shows how the fundamental logic of tax competition differs from the prisoners' dilemma (section 2). Next, we confront the model with data on an archetypical empirical case. Analyzing the tax competition for financial capital in the single European market, we check how far the model can account for the EC's failure to stop this competition through collective action (section 3). As it turns out, the model is quite good at predicting the basic pattern of the competition. Yet, the explanation it offers for the cooperation failure is not entirely convincing. We return to the model, extend it, and refine our argument (section 4). In the concluding section, we summarize our results and point out possible implications for international relations research at large (section 5).

\section{A MODEL OF TAX COMPETITION}

In this section, we develop a simple model of tax competition that allows us to generate a number of testable implications, which subsequently will be applied to our case. Subsections 2.1 to 2.4 develop the model formally and illustrate some of the key constructs graphically. The modeling is interspersed with prose descriptions of the intuition behind concepts, causal mechanisms, and results, so that it should be accessible to readers with only a minimal mathematical training. Readers who nauseate at reading equations may skip directly to subsection 2.5 , which summarizes the main results of the model, without loss of continuity.

\subsection{Building Blocks}

In order to understand the basic strategic pattern of tax competition, we start out with a model that focuses on only a few system-level variables. ${ }^{11}$ The building blocks include a two-country world and one potentially mobile tax base. Index countries $I$ and $I I$. For convenience, we assume that the private sector can be summarized by an aggregate production function yielding a single, homogeneous output good (one might think of it as GDP). We suppose a neoclassical production function, ${ }^{12}$ 


$$
Y_{i}=F\left(K_{i}\right), F^{\prime}>0, F^{\prime \prime}<0, i=I, I I,
$$

where $Y_{i}$ is output, and $K_{i}$, capital input, is the mobile tax base. In the background, there are other inputs, which are assumed fixed and immobile and therefore can be ignored. Since only capital is mobile between the two countries, capital input is subject to diminishing returns.

We suppose that the world capital stock is fixed,

$$
K_{I}+K_{I I}=\bar{K},
$$

where $\bar{K}>0$ is a constant. ${ }^{13}$

In each country, there is a government that needs to raise revenue for welfare, redistribution, and other purposes. To keep the story simple, we make two assumptions: each government is a revenue maximizer and has access to only a single tax instrument, a source income tax on the mobile factor (i.e., capital), where $0<\mathrm{t}_{i}<1, i=I, I I$ is the tax rate. ${ }^{14}$ The after-tax rate of return for the investor, $r_{i}$, is given by

$$
r_{i}=\left(1-t_{i}\right) F^{\prime}\left(K_{i}\right), i=I, I I .
$$

Total tax revenue of the government, $R_{i}$, is

$$
R_{i}=t_{i} F\left(K_{i}\right), i=I, I I,
$$

where we suppose that the source income tax on capital is ad valorem. ${ }^{15}$

\subsection{Tax Policy in Closed and Open Economies}

We can now start to assemble the building blocks and understand the logic of their interaction. The analysis of tax policy depends upon the degree of tax base mobility across states. For analytical clarity, we consider the two polar cases of no mobility and perfect mobility.

In the closed economy, capital cannot move across national borders. It follows that a given country's tax base, $K_{i}$, is essentially fixed and exogenous. However, if $K_{i}$ is fixed, this also implies that total output, $F\left(K_{i}\right)$, is fixed. In this situation, the tax revenue of a country is a monotonically increasing function of the tax rate. In fact, $R_{i}$ is linear in $t_{i}$. The government can extract up to $F\left(K_{i}\right)$ in tax revenue. ${ }^{16}$ This is the "Garden of Eden" situation for the tax state. The upper limit to taxing capacity is defined only by the size of the economy, and there is no policy dilemma.

This stands in marked contrast to the case of perfect transborder mobility. Here, international arbitrage ensures that differences in earnings opportunities are equalized between countries. If the rate of return in one country were lower than in the other, capital owners from the low-return country would shift their assets to the high-return country, until rates of return were equalized. Therefore, there is a unified world rate of return,

$$
r_{I}=r_{I I} \text {, }
$$

which implies that after-tax returns in the two countries are equalized:

$$
\left(1-t_{I}\right) F^{\prime}\left(K_{I}\right)=\left(1-t_{I I}\right) F^{\prime}\left(K_{I I}\right) \text {. }
$$


Due to this arbitrage condition, the equilibrium split of the world capital stock is now endogenous and depends on the tax rates of both countries. To make this functional dependence explicit, consider the following special case of the production function (Cobb-Douglas):

$$
F\left(K_{i}\right)=\left(\frac{1}{\alpha+1}\right) K_{i}^{\alpha+1},-1<\alpha<0,
$$

where $\alpha$ is a parameter that measures returns to scale. It is then possible to obtain closed-form solutions for the two countries' capital stocks:

$$
\begin{aligned}
K_{I}^{*} & =\bar{K}\left(\frac{\tau}{1+\tau}\right), \\
K_{I I}^{*} & =\bar{K}-K_{I}^{*},
\end{aligned}
$$

where

$$
\tau \equiv\left(\frac{1-t_{I I}}{1-t_{I}}\right)^{\frac{1}{\alpha}} .
$$

The arbitrage condition fundamentally alters the logic of taxation. While in the closed economy, the consequences of a change in tax policy are clear-cut-a tax rate increase results in more revenue, a decrease in less-the same is not true for the open economy, where the effects are ambiguous. A tax rate increase may result in more or in less revenue. In order to understand why, consider the case in which one country, say country $I$, takes the other country's (country $I I$ 's) tax rate as given; suppose that the rate is fixed at some exogenous level, $\bar{t}_{I I}$. Then, country $I$ 's tax revenue is given by

$$
R_{I}\left(t_{I}\right)=t_{I} F\left(K_{I}^{*}\left(t_{I}, \bar{t}_{I I}\right)\right) .
$$

What happens if country $I$ raises its tax rate? There are two effects: the direct effect is to increase tax revenue for the given tax base (tax rate effect). The indirect effect is to induce an outmigration of part of the mobile capital stock, reducing the tax base and thus reducing tax revenue at the given tax rate (tax base effect). Since the two effects are conflicting, the net effect is ambiguous. This ambiguity is captured by the Laffer curve, a bell-shaped relationship between total tax revenue and the tax rate. ${ }^{17}$ We can plot the Laffer curve explicitly for a specific parameterization. ${ }^{18}$

Obviously, the optimal tax policy is to select $t_{I}$ to attain the peak of the Laffer curve; denote this by $t_{I}^{*}$.

\subsection{Open Economies in a Nonstrategic Setting}

Is country $I$ 's government better or worse off as a consequence of tax base mobility? In order to answer this question, we need to compare the maximum tax revenue in the mobile and the closed cases. Recall from equation (4) that tax revenue in the closed case is a function of the tax base, $K_{l}$. Tax revenue in the mobile 


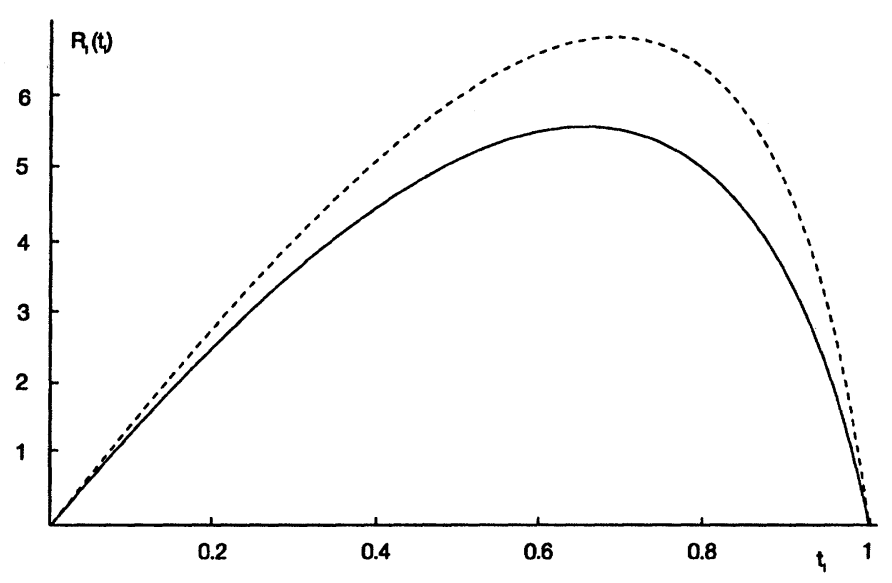

Figure 1. Laffer curve.

case is a function of $t_{I}^{*}$ and not of $K_{I}$. By equating the two quantities, we can solve for the critical level of the initial endowment, $\widetilde{K}_{I}$, which will make country $I$ just indifferent between the two cases insofar as tax revenue is concerned. If country $I$ 's initial tax base is larger than this critical value, the government of country $I$ will be worse off in the mobile case, whereas if country I's initial tax base is smaller than this critical value, the government of country $I$ will be better off in the mobile case.

Formally, we set

$$
F\left(\widetilde{K}_{I}\right)=R_{I}\left(t_{I}^{*}\right)
$$

This implies that $\widetilde{K}_{I}$ is given by

$$
\widetilde{K}_{I}=F^{-1}\left(R_{I}\left(t_{I}^{*}\right)\right){ }^{19}
$$

Whether country I prefers tax base mobility depends on its initial conditions. If it is (initially) small compared to country $I I$, it may benefit from undercutting country II's tax rate because the revenue loss from its limited domestic tax base is likely to be outweighed by the revenue gain from the inflow of a portion of country $I I$ 's tax resources. In such a case, the tax base effect likely swamps the tax rate effect. If, however, country $I$ is (initially) large, it has not much to gain from openness: there is little foreign tax base that could be attracted, and the potential revenue loss of a tax rate cut is large, given the large domestic tax base. The tax rate effect is likely to dominate the tax base effect. Intuitively, preying on foreign tax bases instead of farming domestic tax resources is potentially very profitable, if the foreign economy offers a lot of prey and the domestic economy very little to farm on; it is less useful if domestic farming resources are abundant and foreign prey is scarce. 


\subsection{Tax Competition}

We have now established that at least in a nonstrategic setting, small states will prefer tax base mobility. Next, consider a strategic setting in which the two countries' governments recognize the interdependence of their tax policies and adjust their tax rate in response to changes in their counterpart's tax rate (i.e., true tax competition). Does the small country still profit from tax base mobility, or is it drawn into a downward spiral of tax rate adjustments that in the end leaves it with less tax revenue than in the immobile case? The first step is to find out if this process of mutual adaptation leads to a stable resting point and where this resting point is.

For this purpose, we examine the formal analytics of tax competition. First, we construct the two governments' reaction functions: ${ }^{20}$

$$
\begin{aligned}
& \frac{\partial R_{I}}{\partial t_{I}}\left(t_{I}, t_{I I}\right)=0 \rightarrow t_{I}=\varphi_{I}\left(t_{I I}\right), \\
& \frac{\partial R_{I I}}{\partial t_{I I}}\left(t_{I}, t_{I I}\right)=0 \rightarrow t_{I I}=\varphi_{I I}\left(t_{I}\right) .
\end{aligned}
$$

Next, we search for the noncooperative Nash equilibrium. Formally, it is a pair $\left(\hat{t}_{I}, \hat{t}_{I I}\right)$, satisfying

$$
\varphi_{I}\left(\hat{t}_{I I}\right)=\hat{t}_{I}, \varphi_{I I}\left(\hat{t}_{I}\right)=\hat{t}_{I I} .
$$

Using the same parameterization as in Figure 1, we plot the reaction curves in Figure 2. The interpretation of the reaction curves is as follows: for a given choice by one player, it maps the optimal choice or "best response" by the other player. Thus, the Nash equilibrium must lie at the intersection of the reaction curves, where each player is doing the best it can given the action of the other player.

Evidently, there exists a Nash equilibrium, which is unique and bounded above zero. ${ }^{21}$ This implies that the tax competition game reaches a resting point at a positive level of taxation for both countries. The race to the bottom stops above zero taxation. ${ }^{22}$ Why? The intuitive explanation is simple: tax competition leads to increasingly lower tax rates. Increasingly lower tax rates mean that an additional unit of tax base attracted from the competitor state yields increasingly less fiscal benefit. As a consequence, the gains in terms of the tax base effect decline, while the losses in terms of the tax rate effect increase. Eventually, the net fiscal effect of a further tax rate cut turns negative, and the race comes to a stop. The competition for foreign tax base is subject to diminishing returns and therefore is selflimiting. ${ }^{23}$

This still does not tell us if a small country is better off under tax competition. On first glance, the symmetry of Figure 2 might suggest that the competing countries suffer equally, as in the prisoners' dilemma. But this is not the case because the apparent identity of the two countries is itself a product of the competition. After the process of tax competition has led to a redistribution of the tax base between the two countries, they control equal shares of the tax base, earn identical 


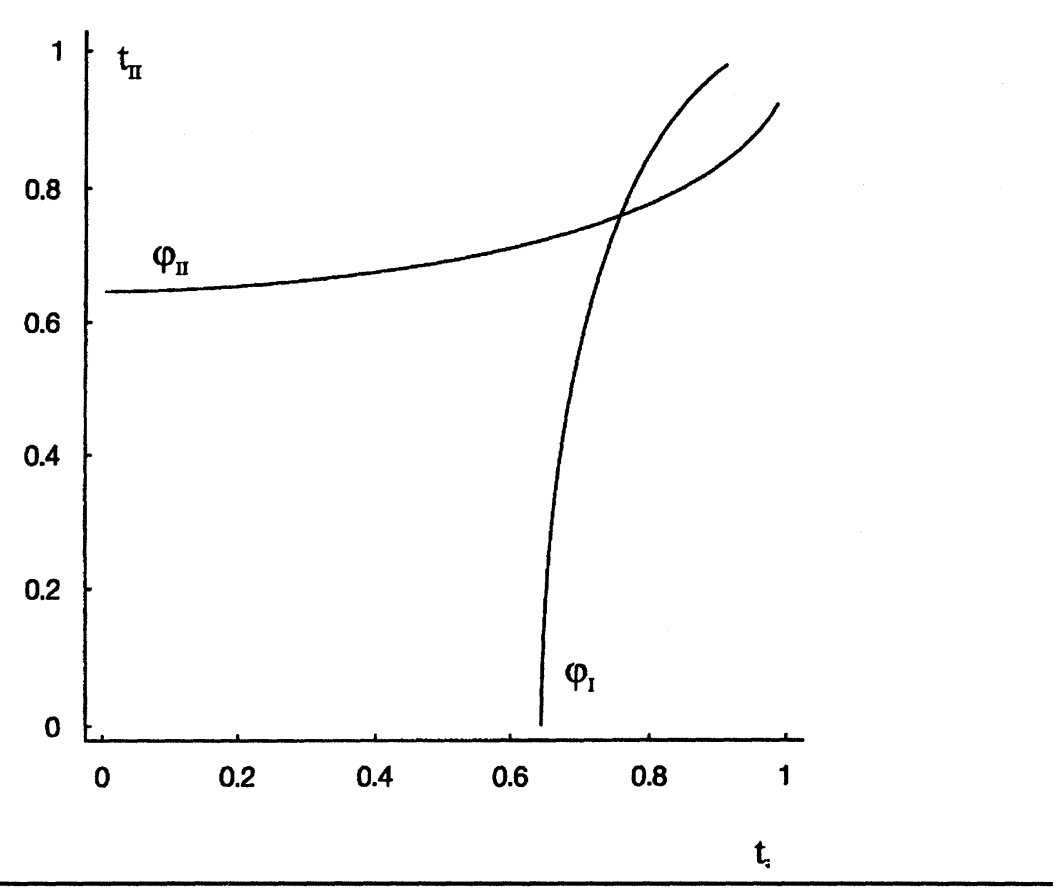

Figure 2. Reaction curves under tax competition.

revenues, and adopt the same calculus to tax policy. But that does not imply that they were also equal before the competition. Hence, the only thing that we can read from Figure 2 is that tax competition will lead to a fall of aggregate tax revenues for both countries taken together. ${ }^{24}$ But this still leaves the possibility that an (initially) small country collects more revenue in the noncooperative equilibrium than in the closed economy case. If it is small enough initially, the tax base effect will swamp the tax rate effect. Indeed, we can again define a critical value for the initial capital stock of, say, country $I$, which would make it just indifferent between the (initially) closed situation and tax competition. Now, we compute the maximum revenue attained by country $I$ in the strategic case; call it $R_{I}\left(\hat{t}_{I}, \hat{t}_{I I}\right)$. As before, we find the critical level of the initial capital endowment, say $\hat{K}_{I}$, at which country $I$ is just indifferent:

$$
\hat{K}_{I}=F^{-1}\left(R_{I}\left(\hat{t}_{I}, \hat{t}_{I I}\right)\right) \text {. }
$$

Hence, the presence of strategic responses by both countries does not alter the logic of the argument embodied in equation (13).

This result implies that if in a two-country world, one country is small and the other large, they will have asymmetric preferences regarding the move from autarky to tax competition: the small country will see an increase in its revenues and the large country a drop. This, in turn, suggests that tax cooperation may not 


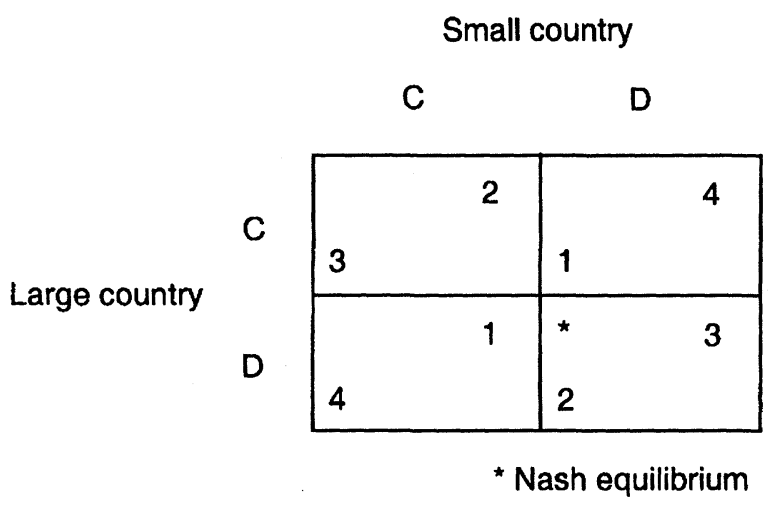

Figure 3. Preferences for tax competition (D) and tax cooperation (C).

necessarily be in the mutual interests of the competing states. Even though it would raise aggregate tax revenues, cooperation would leave the small state with less tax revenue than under tax competition (absent side payments).

\subsection{Why Tax Competition Is Different}

We can now state very precisely why the prisoners' dilemma is a misleading metaphor for tax competition: not because it is wrong, but because it holds under very restrictive circumstances. As the model shows, the prisoners' dilemma is right in assuming that tax cooperation involves a defection problem, but it is erroneous in suggesting that states will always share a mutual interest in solving this problem cooperatively. Only if states are of about equal (initial) size will they share a preference for universal tax cooperation. However, if they significantly differ in size, the smaller states will favor competition to cooperation. The situation, then, changes from a symmetric prisoners' dilemma to a game where one actor with prisoners' dilemma preferences (the [initially] large country) faces another actor with deadlock preferences (the [initially] small country).

In this game, obviously, there is a defection problem: if both actors agree on the c-c outcome, there is an incentive for each of them to defect. But in contrast to the symmetric prisoners' dilemma, there is no evident reason why they should agree on this outcome in the first place. For the small state, cooperation is harmful: it is better off competing. Therefore, if competing countries differ in size, as they are likely to, we should expect that the real issue for tax cooperation is not defection ex post but disagreement ex ante about the desirability of cooperation.

\section{EMPIRICAL EVIDENCE}

Does this prediction make empirical sense? As a first cut, we confront the model with an archetypical case of tax competition: the competition among the 
member states of the European Community in the taxation of financial income (interest income from savings and bonds). The case promises to be particularly instructive on three grounds. First, savings and bonds are a very mobile tax base, ${ }^{25}$ so that the competition for this base should be especially pronounced and its attendant problems easy to observe. Second, the EC has a well-developed institutional infrastructure for the maintenance of agreements. If the member states nevertheless fail to stop the competition, we can safely infer that the reason is not their inability to deal with the defection problem. Third, there is a significant discrepancy in country size: four large countries-Germany, France, Italy, and Britaincompete with much smaller countries such as Luxembourg, Belgium, or the Netherlands. If country size does indeed play a role in tax competition, this case should bear it out.

\subsection{The Agonies of Tax Cooperation}

In 1987, the European Commission proposed a directive eliminating all capital controls within the EC. The free movement of capital was generally welcomed by the member states as an important step toward a single European capital market. But it also aroused fears of tax competition and fiscal degradation. Some economists worried that the single market would transform the European Community "into a single (large) tax haven." ${ }^{26}$ France and Italy were particularly concerned that the liberalization of capital movements would undermine their fiscal position.

In order to calm these fears, an additional paragraph was added to the capital movements directive before it was passed in June $1988 .{ }^{27}$ It instructed the Commission to make proposals on how to prevent tax competition and committed the Council to decide on these proposals by mid-1989. ${ }^{28}$ In keeping with this task, the Commission in February 1989 proposed the introduction of a common 15 percent withholding tax on interest income from savings and bonds. Some member states already levied such taxes, but the tax rates differed widely, and some member states did not levy any withholding taxes at all-Luxembourg, the Netherlands, and Denmark. A common tax rate seemed necessary to prevent free capital movements and tax arbitrage from creating a race toward the bottom.

The response of the member states was mixed. The British government flatly denied the necessity for any tax coordination and criticized the withholding tax plan as a disguised retreat from the full consequences of free capital movements. Luxembourg complained that the proposed tax was "anti-European" and would drive money away from the EC to financial centers in the outside world. If there was to be any tax cooperation at all it should be arranged on a higher plane, such as the OECD, where the most important non-EC financial centers are also involved. To varying degrees, the Netherlands, Greece, and Denmark also raised objections to the Commission's proposal, while the Italian government thought that it did not go far enough. ${ }^{29}$ 
As the controversy unfolded, Germany's position turned out to be pivotal. In January 1989, the German government had introduced a national withholding tax on savings and bonds to combat excessive tax fraud in capital income taxation. The similarity of the new German tax to the Commission's proposal-and the near coincidence of its introduction-worked as a powerful reinforcement. In April 1989, however, in an unexpected reversal of policy, the German government decided to abolish the tax, supposedly because it had done serious harm to German capital markets. The announcement of the tax had led many German investors to buy DM-Eurobonds and other tax-free offshore assets instead of lending in the domestic market. This had contributed to a record outflow of funds in 1988. The DM exchange rate came under pressure, domestic bond yields rose, and it became more expensive for German residents, including the government, to borrow in DM than for nonresidents. Germany, it was feared, would lose attractiveness as a location for financial services. ${ }^{30}$

Since Germany joined the ranks of the dissenters in EC negotiations as well, the chances of winning unanimous agreement on a common European withholding tax were dashed. In May 1989, during a meeting of EC finance ministers, the Commission's proposal was quietly laid to rest. ${ }^{31}$ The problem of tax competition did not go away, however. Upon capital liberalization, a couple of member states lowered their withholding tax rates or extended tax exemptions in order to prevent domestic funds from flowing out and encourage foreign funds to flow in. This was particularly true of Belgium, which, while a small country in the EC context, is the large partner in the currency union with Luxembourg. In early 1990, the government slashed the withholding tax rate from 25 percent to 10 percent to stem the steady drain of Belgian funds to its tiny, withholding tax-free and secretive neighbor. ${ }^{32}$

At the same time, the Belgian government continued to look for multilateral ways to limit tax competition. In 1993, it joined forces with Germany to relaunch the plan for a common withholding tax. As of January 1993, Germany had reintroduced a national withholding tax and again suffered from a massive outflow of funds. The main beneficiaries were Luxembourg and the German banks doing business there. The main loser was the federal treasury. In 1993, it took in DM 11 billion of gross revenues from the new withholding tax instead of DM 24 billion as initially projected. ${ }^{33}$ Struggling to finance German unification, the government demanded Community action to plug the "loophole" Luxembourg. ${ }^{34}$

The British government was most outspoken in its criticism of the BelgianGerman initiative. It argued that a common withholding tax would drive business away to New York and Tokyo and called for a free market in taxation. Luxembourg was equally opposed to the tax, reiterating that the $\mathrm{EC}$ was the wrong forum for tax cooperation. Common rules and rates should be introduced on the OECD level rather than just among the EC member states. ${ }^{35}$ The Netherlands criticized technical details of the plan. Germany went out of its way to secure agreement. 
But in late 1994, it became clear that the rerun of the withholding tax plan had failed like its predecessor.

The next attempt to relaunch tax cooperation was started in the spring of 1996 . The Commission issued a report on the dangers of tax competition and asked the member states to agree on a comprehensive package of measures to defend fiscal revenues from erosion. ${ }^{36}$ Struggling to meet the Maastricht fiscal criteria, France, Germany, and Italy looked quite positively upon attempts to regulate tax competition. ${ }^{37}$ Yet the negotiations proved to be difficult. A tax policy group of national officials met several times during 1997 to work out a deal but was able to do so only by dropping the contentious issues from the agenda. When finally, in December 1997, the finance ministers signed a "code of conduct" for tax policy, it was nonbinding in nature and restricted in purpose. ${ }^{38}$ Interest taxation is not covered at all. Some member states had hoped to make it one of the agreement's key elements, but the issue proved too controversial. All that was agreed upon was that the Council of Ministers should come back to this issue at a later date. But then, this was already agreed to in 1988 .

\subsection{Explaining the Failure}

Does our model help to account for this story? Do its predictions hold? Four implications are particularly relevant. The first is that upon capital liberalization, all member states, large and small, should reduce the tax burden on interest income in order to lure foreign tax base into the country and discourage domestic tax base from leaving. The second is that this process of tax competition should lead to tax base losses for the large countries and tax base gains for the small countries. In the end, the small member states should command a disproportionately large share of the interest income tax base (relative to their initial endowments). The third is that the competition should result in improved fiscal revenues of the small and deteriorated revenues of the large states. Finally, the fourth implication is that the large countries should sponsor tax cooperation, while the small states should boycott it. We will discuss each of these predictions in turn.

\section{Tax Burden}

The discussion of the first prediction, that tax competition will lead governments to reduce the tax burden on interest income, is complicated by two factors. First, in contrast to our simple model, the tax rate is not the only determinant of the tax burden. It also depends on the tax base definition. If this definition is changed, for example, by introducing new tax exemptions for part of the interest income tax base, the tax burden falls, even if the tax rate remains unchanged. Second, and again in contrast to the model, it is not obvious which tax rate is relevant for the determination of the tax burden.

In general, interest income is taxed twice, first at the source, where it is generated, and then as part of the general income tax of the investor who receives it. 
Table 1

Withholding Taxes on Nonresident Interest Income

\begin{tabular}{|c|c|c|c|c|c|c|}
\hline \multirow[b]{3}{*}{ States } & \multicolumn{3}{|c|}{ Savings } & \multicolumn{3}{|c|}{ Bonds } \\
\hline & \multicolumn{2}{|c|}{ Tax Rate $(\%)^{\mathrm{a}}$} & \multirow{2}{*}{$\begin{array}{c}\begin{array}{c}\text { Direction } \\
\text { of Change }\end{array} \\
1989-1996\end{array}$} & \multicolumn{2}{|c|}{ Tax Rate $(\%)^{\mathrm{a}}$} & \multirow{2}{*}{$\begin{array}{c}\text { Direction } \\
\text { of Change }\end{array}$} \\
\hline & 1989 & 1996 & & 1989 & 1996 & \\
\hline Belgium & 25 & 0 & - & 25 & 0 & - \\
\hline Denmark & 0 & 0 & 0 & 0 & 0 & 0 \\
\hline France & $46^{\mathrm{b}}$ & 0 & - & $25^{\mathrm{b}}$ & $0-15^{b}$ & - \\
\hline Germany & 10 & 0 & - & 10 & 0 & - \\
\hline Greece & 0 & $15^{\mathrm{b}}$ & + & 56 & $15^{\mathrm{b}}$ & - \\
\hline Italy & $30^{\mathrm{b}}$ & 30 & 0 & $30^{\mathrm{b}}$ & 12.5 & - \\
\hline Ireland & 0 & 0 & 0 & 35 & $27^{b}$ & - \\
\hline Luxembourg & 0 & 0 & 0 & 0 & 0 & 0 \\
\hline Netherlands & 0 & 0 & 0 & 0 & 0 & 0 \\
\hline Portugal & 15 & 20 & + & 10 & $25^{\mathrm{b}}$ & + \\
\hline Spain & 20 & $25^{\mathrm{b}}$ & + & 20 & $25^{\mathrm{b}}$ & + \\
\hline United Kingdom & 0 & 0 & 0 & $25^{\mathrm{b}}$ & $25^{\mathrm{b}}$ & 0 \\
\hline
\end{tabular}

Source: Bundesministerium der Finanzen, Informationsdienst zur Steuerpolitik des Auslands (Bonn: BMF 1988, 1996).

a. General rates; no double taxation, no special tax rate exemptions.

b. Various special rates and exemptions for special types of investment.

Which tax determines the final tax burden? If all investors were honest and reported all their income, this role would clearly fall to the general income tax because the withholding tax is usually treated as a prepayment on this tax. Very often, however, investors have little incentive to be honest because the tax authorities cannot independently verify their income. This is especially true with respect to income earned on foreign investment. According to OECD tax expert Jeffrey Owens, income taxes paid on such investments are "almost a voluntary tax." 39 Consequently, the only tax levied on this type of income is often the withholding tax charged by the foreign source country. Therefore, the (technically) appropriate strategy to lure foreign tax base is to undercut one's neighbor's withholding taxes on nonresident income. As Table 1 shows, this is what the EC member states did, once capital movements were liberalized in 1990.

Table 1 reports fourteen instances of tax rate change, nine of which involve tax rate cuts and only five tax rate increases. Significantly, four of the five rate hikes went hand in hand with the introduction of new tax exemptions (marked by [b]), which, by narrowing the tax base definition, mitigated or even offset the effects of the increase in the rate. By and large, therefore, the data seem to support the prediction that tax competition leads all member states to reduce taxes on interest income.

Is it also true, then, that they reduce taxes on interest income to keep the domestic tax base from moving out? The case is more complicated because income taxes on domestic interest income are less easy to evade, especially if the country operates an automatic reporting system (marked by [c] in Table 2), which obliges 
Table 2

Withholding Taxes/Top Personal Income Taxes on Resident Interest Income

\begin{tabular}{|c|c|c|c|c|c|c|}
\hline \multirow[b]{3}{*}{ States } & \multicolumn{3}{|c|}{ Savings } & \multicolumn{3}{|c|}{ Bonds } \\
\hline & \multicolumn{2}{|c|}{ Tax Rate $(\%)^{\mathrm{a}}$} & \multirow{2}{*}{$\begin{array}{c}\begin{array}{c}\text { Direction } \\
\text { of Change }\end{array} \\
1989-1996\end{array}$} & \multicolumn{2}{|c|}{ Tax Rate $(\%)^{\mathrm{a}}$} & \multirow{2}{*}{$\begin{array}{l}\begin{array}{c}\text { Direction } \\
\text { of Change }\end{array} \\
1989-1996\end{array}$} \\
\hline & 1989 & 1996 & & 1989 & 1996 & \\
\hline Belgium & $25^{\mathrm{b}}$ & $15^{\mathrm{b}}$ & - & $25^{\mathrm{b}}$ & $15^{\mathrm{b}}$ & - \\
\hline Denmark & $0 / 68^{\mathrm{c}}$ & $0 / 62^{c}$ & - & $0 / 68^{\mathrm{c}}$ & $0 / 62^{c}$ & - \\
\hline France & $0 / 57^{c}$ & $19 / 57^{c}$ & + & $0 / 57^{c}$ & $19^{\mathrm{b}, \mathrm{c}}$ & - \\
\hline Germany & $10 / 56$ & $32 / 57$ & + & $10 / 56$ & $32 / 57$ & + \\
\hline Greece & $0 / 63$ & $15^{b, d}$ & - & $25 / 63$ & $15^{\mathrm{b}, \mathrm{d}}$ & - \\
\hline Italy & $30^{\mathrm{b}}$ & $30^{\mathrm{b}}$ & 0 & $12.5^{\mathrm{b}}$ & $12.5-30^{b}$ & + \\
\hline Ireland & $35 / 58$ & $27 / 48$ & - & $35 / 58$ & $27 / 48$ & - \\
\hline Luxembourg & $0 / 56$ & $0 / 51$ & - & $0 / 56$ & $0 / 51$ & - \\
\hline Netherlands & $0 / 72^{\mathrm{c}}$ & $0 / 60^{\mathrm{c}}$ & - & $0 / 72^{\mathrm{c}}$ & $0 / 60^{c}$ & - \\
\hline Portugal & $15 / 60$ & $20^{\mathrm{b}}$ & - & $10 / 60$ & $25^{\mathrm{b}, \mathrm{d}}$ & - \\
\hline Spain & $20 / 56$ & $25 / 56^{\mathrm{c}}$ & + & $20 / 56$ & $25 / 56^{\mathrm{c}}$ & + \\
\hline United Kingdom & $23 / 40$ & $25 / 40$ & + & $25 / 40$ & $25 / 40$ & 0 \\
\hline
\end{tabular}

Source: Bundesministerium der Finanzen, Informationsdienst zur Steuerpolitik des Auslands (Bonn: BMF 1988, 1996).

a. Withholding tax rates are general rates; no double taxation agreements, no special tax rate exemptions; personal income rates are top marginal rates.

b. Withholding tax is treated as final tax.

c. Automatic reporting.

d. Various special rates and exemptions for special types of investment.

banks to pass financial information to the tax authorities like in the Netherlands, Denmark, or France (as also in the United States). Hence, the tax burden on domestic interest income depends to a larger degree on the general income tax. This makes the reduction of this specific burden difficult. Basically, there are only two options. Either the general income tax is reduced, but that would also reduce taxes from immobile sources of income, which are not subject to tax competition. Or interest income is exempted from the general income tax and taxed separately at a lower rate. But this then raises the politically delicate issue of why (wealthy) capital owners should pay less tax on their interest income than (less wealthy) workers pay on their wages. Given these difficulties, it is remarkable that both options were tried nevertheless.

Table 2 shows that the tax burden on resident interest income has been reduced in fifteen cases between 1989 and 1996, while it was increased in only seven cases. Sometimes, the top marginal income tax rate was reduced significantly, as, for example, in the Netherlands, and sometimes interest income was exempted from the general income tax, turning the lower withholding tax into the final tax (marked by [b]) as, for example, in Portugal. We may conclude that the member states did indeed reduce their claims to interest income tax as the model implies. 
Table 3

Investment Fund Assets in Large and Small EC Member States

\begin{tabular}{lccccc}
\hline & \multicolumn{2}{c}{ Stock (bn \$) } & & \multicolumn{2}{c}{ Growth (1990-1995) } \\
\cline { 2 - 3 } \cline { 5 - 6 } EC-12 & 1990 & 1995 & & Absolute (bn \$) & Relative (\%) \\
\hline Small states & 150 & 523 & & 373 & 249 \\
Large states & 583 & 902 & & 319 & 55 \\
Total & 733 & 1.425 & & 692 & 94 \\
\hline
\end{tabular}

Source: HSBC James Capel, Major Themes within the UK Fund Management Industry (London: HSBC, 1996), own calculations.

\section{Tax Base}

Did the tax competition lead to tax base gains in small and tax base losses in large countries? There is no systematic survey of tax-induced cross-border portfolio flows in the single market. ${ }^{40}$ But there is the well-documented case of Germany and Luxembourg: when Germany introduced a 10 percent withholding tax on interest income in 1989, roughly DM 100 billion of financial capital fled within a year and a half. ${ }^{41}$ The reintroduction of a withholding tax in 1993 also led to large-scale capital flight. ${ }^{42}$ The vehicle of choice for German tax evaders was Luxembourg investment funds. ${ }^{43}$ German investment in these funds jumped more than fivefold, ${ }^{44}$ leading to faster growth and higher capitalization of the Grand Duchy's fund industry as compared to its German counterpart. It seems fair, therefore, to take investment funds as a rough indicator for the tax-sensitive interest income tax base. This allows us to check if the "small countries gain" prediction also holds true for the EC at large. If the prediction is valid, we should observe that after capital liberalization, the investment fund industry in small EC member states grew faster and attracted a larger share of total European investment than the fund industry in large EC states.

Table 3 seems to corroborate the diagnosis. Dividing the EC into a group of small states-Luxembourg, Ireland, Greece, Portugal, Denmark, Belgium, Netherlands, and Spain ${ }^{45}$ - and a group of large states-United Kingdom, Italy, France, and Germany-it shows a significant discrepancy in the growth of investment fund assets between the two. In the small states, growth was somewhat stronger in absolute terms and, since it started from a much lower base, significantly stronger in relative terms. As a consequence, the small states' share in the total European investment fund market has increased markedly (see Table 4).

While in 1990 the small states' share of the total European investment fund market was almost equal to their share of total EC GDP (20 percent as compared to 21 percent), by 1995 the former had grown significantly larger than the latter ( 37 percent as compared to 22 percent). If we accept GDP as a proxy of initial size, this suggests that the small states have indeed attracted a disproportionately large share of the European interest tax base, just as the model would lead one to expect. 
Distribution of Investment Fund Assets among Large and Small EC Member States

\begin{tabular}{|c|c|c|c|c|}
\hline & \multicolumn{2}{|c|}{ Share of EC-12 GDP (\%) } & \multicolumn{2}{|c|}{$\begin{array}{c}\text { Share of EC-12 } \\
\text { Investment Fund Assets (\%) }\end{array}$} \\
\hline & 1990 & 1995 & 1990 & 1995 \\
\hline Small states & 21 & 22 & 20 & 37 \\
\hline Large states & 79 & 78 & 80 & 63 \\
\hline
\end{tabular}

Source: HSBC James Capel, Major Themes within the UK Fund Management Industry (London: HSBC, 1996), Eurostat Jahrbuch 1997; own calculations.

\section{Tax Revenue}

Is it also true, then, that the small countries' tax base gain translates into improved fiscal revenues? Unfortunately, there is no quantitative estimate, but anecdotal evidence suggests that the inflow of financial capital did indeed improve the small states' fiscal standing. Note, however, that in the real world, the tax base effect often works less straightforwardly than in our simple model. Take Luxembourg as an example. Given a zero withholding tax, the Luxembourg treasury does not directly benefit from increased foreign financial investment. But it does so indirectly because increased investment means increased financial intermediation, which in turn means increased tax receipts from the financial services sector. ${ }^{46}$ The reintroduction of withholding taxes in Germany, for instance, led to an increase in the number of foreign banks in Luxembourg from 187 in 1992 to 213 in $1993 .{ }^{47}$ As a result of Luxembourg's growth as a financial center, nearly 20,000 people work directly in banking and up to 7,000 more in related legal, advisory, and other activities. Banking and investment account for more than 15 percent of GDP and 40 percent of tax revenues (including banks and their employees) ${ }^{48}$ Likewise, it has been suggested that tax competition accounts for the recent improvement of public finances in the Netherlands, Belgium, and Ireland and the concomitant deterioration in Germany. ${ }^{49}$ It is at least interesting to note that the government debt ratio has, during the past few years, deteriorated in all large member states while it has improved in all small states but two. ${ }^{50}$

\section{Tax Cooperation}

Even if the model is quite good at predicting the winners and losers of tax competition, it is not as good at predicting policy preferences on tax cooperation. In the withholding tax case, not all losers favored harmonization, and not all winners favored continued competition. Germany's, France's, and Italy's support for, as well as Luxembourg's staunch opposition to, the introduction of a common European minimum withholding tax fit the pattern, but the United Kingdom's resistance to and Belgium's support for a common withholding tax clearly do not. Given the former Conservative government's sovereignty-mindedness and free market zeal, the British stubbornness probably does not come as a surprise. But it 
Table 5

Government Debt as a Percentage of GDP

\begin{tabular}{lrrc}
\hline & 1993 & 1997 & Change Percentage Points \\
\hline Small states & & & \\
$\quad$ Luxembourg & 6.1 & 6.7 & +0.6 \\
Ireland & 96.3 & 66.3 & -30.0 \\
Greece & 111.6 & 108.7 & -2.9 \\
Portugal & 63.1 & 62.0 & -1.1 \\
Denmark & 81.6 & 65.1 & -16.5 \\
Belgium & 135.2 & 122.2 & -13.0 \\
Netherlands & 81.2 & 72.1 & -9.1 \\
Spain & 60.0 & 68.8 & +8.8 \\
Large states & & & \\
$\quad$ United Kingdom & 48.5 & 53.4 & +4.9 \\
Italy & 119.1 & 121.6 & +2.5 \\
France & 45.3 & 58.0 & +12.7 \\
Germany & 48.0 & 61.3 & +13.3 \\
\hline
\end{tabular}

Source: European Commission, Convergence Report (Brussels: European Commission, 1988).

is inexplicable in terms of our model's systemic-level variables. Belgium's "anomalous" behavior, by contrast, can at least in part be accounted for by a systemic-level factor: its currency union with the even smaller Luxembourg. The behavior of the rest of the small states is ambiguous. Some of them, most notably the Netherlands and Denmark, raised objections to the proposal of a common withholding tax but never went so far as to threaten to block tax cooperation altogether. Prima facie, this would seem to contradict the model. On closer inspection, it may turn out, however, that these countries just strategically misrepresented their true preferences: since the vociferous opposition of the United Kingdom and Luxembourg already ensured that the withholding tax plan would not come about, there simply was no reason for them to signal their opposition truthfully and thereby attract the wrath of France, Germany, and Italy.

\section{THE OUTSIDE WORLD CONSTRAINT}

The preceding section has shown that the model does fairly well at forecasting the general trends toward which patterns of behavior converged under interest tax competition in Europe. Even so, there are problems with the explanation it offers for the failure of tax cooperation. In terms of the model, a critical reader may wonder why a small state can siphon off a large state's tax base without ever being punished. Why does the large state not make the small state behave? Why does it not use its power to change the payoffs faced by the small state? ${ }^{51}$ In terms of the case study, she may ask how Luxembourg and the United Kingdom-a midget-state and an ideologue-could possibly have been powerful enough to block tax cooperation for an extended period of time, despite its salience for notionally powerful 
states such as France and Germany. It is hard to imagine that Luxembourg should not be susceptible to threats or side payments, and even the United Kingdom, while larger and less easy to bully, has often been forced to accept outcomes that it does not prefer. Witness the negotiations leading up to the Single European Act, where Germany and France exploited the threat to exclude the United Kingdom from the single market project to coax the British government into agreement. ${ }^{52}$ Evidently, the cause of cooperation failure in tax harmonization was not only the opposition of the United Kingdom and Luxembourg but also the lack of resolve of the pro-cooperation states to overcome this opposition by appropriate threats or inducements.

Important hints may be gleaned from the case study as to what might lie behind this remarkable lack of resolve. As will be recalled, Luxembourg and the United Kingdom routinely raised the specter of intra-EC tax cooperation being exploited by extra-EC jurisdictions to justify their opposition. Instead of generating additional tax revenues for EC member states, they argued, withholding tax harmonization would result in a massive capital outflow to the outside world. Obviously, this argument provided an ideal cover for their political intentions. But even the proponents of withholding tax harmonization admitted to its potential validity.

When in the late 1960s the Commission first raised the idea of a common withholding tax, it acknowledged that this would result in capital flight to non-EC countries unless complemented by the introduction of a common system of capital controls at the outer perimeters of the Community. ${ }^{53}$ In the late 1980 s, the notion of capital controls was no longer politically feasible. The capital movements directive of $1988^{54}$ made it impossible to use controls to either seal off a "tax cooperation zone" within the single market or ring-fence the single market vis-àvis the outside world. Instead, the Commission proposed to hedge against the risk of capital flight to non-EC countries by restricting the coverage of the proposed withholding tax, suggesting a large number of loopholes for nonresident investors and Euro-securities. This, however, reduced the potential fiscal benefits of the tax and, by inference, the ability to generate rents to be distributed to the opponents. ${ }^{55}$ As a consequence, the pro-cooperation states could neither credibly threaten potential noncooperators with selective exclusion nor could safely assume that tax cooperation would generate large surpluses that could be used for side payments.

This, then, raises the fundamental question of how much collective benefit could the EC members realistically expect from tax cooperation. Our simple two-country model suggests that cooperation would raise aggregate world tax revenues. But in a now-famous paper, economist Roger Gordon warns that in a multicountry world with full capital mobility, "there should not be important gains from coordination within any small group" $" 56$ because most of the cooperation benefits will leak to the noncooperating outside world. 


\subsection{Partial Cooperation and the Leakage Effect}

With a straightforward extension of the two-country model, we can submit Gordon's intuition to formal analysis. For this purpose, we consider an $n$-country world. Index countries by $i=1, \ldots, n$. All other building blocks of the model remain the same. As before, we summarize the private sector by an aggregate production function (equation (1)), and again we specialize to the Cobb-Douglas type (equation (7)). The world capital stock is fixed (by analogy to equation (2)), and the revenue-maximizing governments are still restricted to a single policy instrument: a source income tax on the mobile factor (i.e., capital).

To consider the implications of tax competition in this setting, we move immediately to the case of the open economy. As the reader will recall, after-tax rates of return must be equalized across all countries in this setting (by analogy to equation (5)). With this specification, we obtain the following closed-form solutions for the equilibrium capital stocks:

$$
K_{i}^{*}=\frac{\bar{K}}{1+\sum_{j \neq i}\left(\frac{1-t_{j}}{1-t_{i}}\right)^{\frac{1}{\alpha}}}, i=1, \ldots, n,
$$

where each country's capital stock, $K_{i}^{*}$, depends on the world capital stock, $\bar{K}$, and on every country's tax rate, $t_{j}$. Each country's revenue function is defined analogously to equation (4). As a reference point, we can construct, as in the twocountry model, the noncooperative Nash equilibrium, found by deriving the reaction functions for all $n$-countries and solving for the fixed point (by analogy to equation (16)).

What are the prospects for partial cooperation in this model? Suppose that a fixed subset, $m \leq n$, of countries coordinate tax policies among themselves to maximize their joint tax revenue and then engage in noncooperative Nash behavior with the outside world: ${ }^{57}$ technically, a nested noncooperative Nash equilibrium. Does cooperation help the $m$-group to improve collective revenue over and above what it would obtain in the noncooperative case? While the model is not amenable to easy analytical solution because of the inherent nonlinearity of the reaction curves, it is straightforward to generate numerical simulation results. Figure 4 plots member (cooperator) and outsider (noncooperator) revenue for specific parameter values. ${ }^{58}$

Inspecting the simulation results, it is evident that the $m$-group's collective revenue under cooperation falls short of the collective revenue under tax competition. Partial cooperation is collectively immiserizing for the cooperators. The collective revenue of the outsiders exceeds the collective revenue of the cooperators for every $m$-group smaller than the "grand coalition" $(m=n){ }^{59}$

The result provides theoretical confirmation of Gordon's skepticism and establishes the centrality of the "outside world constraint." The fact that attempts to coordinate capital taxes inevitably take place among a subset of potential 


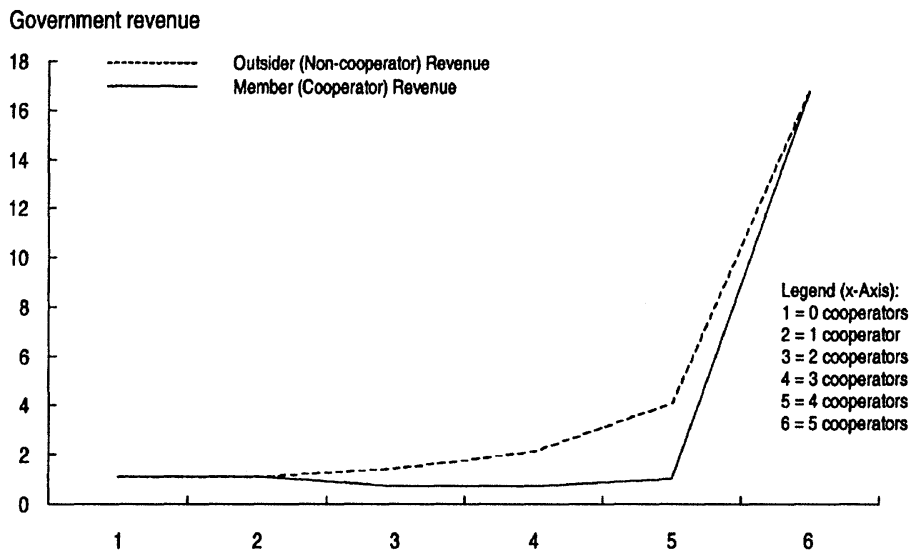

Figure 4. Member versus outsider revenue.

cooperators significantly and, in the model itself, critically impinges on the likely profitability of these attempts. As the $m$-group starts to cooperate, part of the mobile tax base migrates to the outside world in search of a lower tax burden. Given perfect capital mobility, this "leakage effect" implies that the benefits from tax cooperation do not accrue to the cooperating countries but rather to the noncooperating bystanders. Noncooperation, while inferior to global cooperation, is actually better than partial cooperation.

\subsection{Tax Creation and Tax Diversion}

The problem with this theoretical result is that it is so stark. It does not explain why large states may be hesitant to bribe small states into agreement on tax harmonization or, more specifically, why France and Germany may have been reluctant to offer side payments to Luxembourg. Rather, it shows that partial tax cooperation is a bad idea in the first place and hence obscures why any rational government would ever pursue it. Is there something that the model misses? Probably so.

The analogy with customs union theory is illuminating here because it shows that the effects of partial cooperation may be more ambiguous than suggested by Gordon's intuition and our extended model. Customs union theory analyzes under what circumstances it is beneficial or detrimental for states to abolish tariff barriers between themselves and set a common tariff vis-à-vis the outside world. Intuition might suggest that any move toward free trade among a subset of trading nations would be advantageous for the cooperators. But this is not necessarily the case. $^{60}$ The removal of intraunion tariff barriers may result in "trade diversion"- $-a$ shift of demand from nonunion sources to higher cost union suppliers-or in "trade creation"- - a demand shift from domestic production to lower cost output 
from a union partner. Only if trade creation dominates trade diversion are the cooperators likely to benefit. If trade diversion prevails, the cooperation will likely be immiserizing for the cooperators.

The parallel between the concept of trade diversion and the leakage effect of our extended model is obvious. Indeed, the leakage of part of the mobile tax base can be thought of as "tax (base) diversion." But is there also an equivalent to trade creation? Obviously, the model has no scope for "tax creation," but that does not mean that sources of tax creation do not exist. The Commission often argues, for example, that capital tax harmonization will reduce bureaucratic waste and enhance efficiency by facilitating tax administration and increasing the transparency of the European capital market. This, in turn, may lead to faster growth and higher tax revenues for the member states as a whole. ${ }^{61}$

Quite apart from the possibility of tax creation, the existence of imperfect capital mobility between the European capital market and the rest of the world suggests that the losses from tax diversion may be more muted than our model suggests. Despite what is nowadays often assumed, there is evidence that international capital is not perfectly mobile. Indicators include a high correlation between domestic savings and investment, considerable real interest differentials across countries, and a heavy specialization of individual portfolios in domestic securities despite large potential gains from international diversification. ${ }^{62}$ In a recent paper, Gordon and Lans Bovenberg suggest that the reason behind this lack of mobility is asymmetric information: capital owners hesitate to put their money abroad because they may be at a handicap due to their poor knowledge of local conditions. ${ }^{63}$ Political uncertainty and currency risk may further dampen crossborder capital mobility ${ }^{64}$ In light of these factors, it seems plausible to assume that European capital owners are "single market biased": political risks are minimal, legal conditions are harmonized, and exchange rate fluctuations are low. ${ }^{65}$ This bias would tend to limit the scope of tax diversion.

Anecdotal evidence corroborates the point. German economists have observed, for example, that the main reason for the high level of German tax evasion to Luxembourg is that in Luxembourg, German tax evaders can do business with the same banks as at home. If the presence of German banks was smaller, and tax evaders would have to entrust their money to foreign banks, many of them would find the transaction costs of evasion too high, and the level of evasion would be lower. ${ }^{66}$ Likewise, Commission officials half jokingly argue, in informal conversation, that private investors often take a "Mercedes-length" approach to tax evasion, meaning that they never put their money in a place farther away than a Mercedes tank-full. Both observations suggest that the inclination to evade tax may be higher within the single market than across the single market's outer boundaries. It appears doubtful, therefore, that high levels of tax evasion between, say, Germany and Luxembourg really indicate that tax evasion between the EC and the rest of the world would be equally high, as is sometimes suggested in the 
literature ${ }^{67}$ Given less than perfect mobility between the European capital market and the rest of the world, the introduction of a common withholding tax might result in less leakage and more additional tax revenue than the GermanyLuxembourg example would lead one to expect. ${ }^{68}$

However, the only way to find out for sure is, in fact, to try. Ex ante, it is impossible to know with any certainty how large the tax diversion effect of a common withholding tax will be and if it will dominate tax creation or be in turn dominated by it. While this fundamental uncertainty affects all political actors alike, it works decisively to the political advantage of the opponents of tax harmonization. They can operate from the safe grounds of the worst-case scenario of perfect capital mobility, while the proponents have to base their plans on the assumption that the worst case will not occur. There is a risk, however unlikely, that the worst case may appear, and up to now, the pro-cooperation countries have avoided taking it. They have put forward the withholding tax plan, but they have not invested much in buying off the opposition in the Council. Eventually, fiscal desperation and the prospect of heightened tax competition under monetary union may push them over the brink. But the potential for regret is large: if they find that tax creation outweighs tax diversion, they may regret that they have waited for so long; if, in contrast, they find that the diversion effect dominates the creation effect, they will regret that they could ever have been so reckless as to embark on such a risky project. The prospects are uncomfortable and exemplify the Solomonic insight of the "general theory of the second best": an incomplete move toward the optimum-tax cooperation across some but not all relevant countries-may make matters either better or worse. ${ }^{69}$

\section{CONCLUSION}

Why does collective action so persistently fail in tax competition? The prisoners' dilemma metaphor suggests that the reason is a defection problem. Yet, as we have argued, it is not obvious why this problem should be more intractable in taxation than in other policy fields, where European and international cooperation has dealt with it quite successfully. Our model confirms the existence of the problem: if states agree to fix taxes at a certain level, each of them has an incentive to undercut it. But it also shows that such agreement is unlikely in the first place: while tax competition reduces world aggregate tax revenue, it improves the individual revenue position of small states. These states, therefore, have no incentive to cooperate. They are better off under tax competition-unless they receive sufficient side payments to make cooperation worth their while.

The fact that cooperation improves aggregate tax revenue would seem to suggest that there is enough room to make such side payments mutually beneficial. However, as our extended model shows, this may hold only in the extreme case of universal cooperation, if capital is perfectly mobile. If tax cooperation remains restricted to a subset of competing states, the cooperation benefit will not fully 
accrue to the cooperators, but part of it will leak to the outside world: the tax base that had moved to the small states under tax competition may not flow back to the large states but move on to the remaining tax havens in the noncooperating outside world. This leaves the governments of large countries with the unattractive choice of seeking global tax cooperation, which for practical reasons is largely illusory, or regional cooperation, which, due to the outside world constraint, is of only limited use and possibly self-harming. We surmise that this dilemma, rather than an unmanageable defection problem, is at the heart of the continuous failure to institute tax cooperation in Europe or worldwide.

The tax competition case draws attention to two strategic problems that have received little attention in international relations research: the problem of lack of mutual interest and the problem of a noncooperating outside world. The recent literature on "cooperation theory" and the "neoliberal institutionalism" does not address them at all but focuses almost exclusively on the analysis of coordination problems, as typified by the $(2 \times 2)$ Battle of the Sexes game, and defection problems, as embodied in the $(2 \times 2)$ prisoners' dilemma. Both games differ in important respects. ${ }^{70}$ But they share two important features: first, cooperation is mutually beneficial-everybody is better off under universal cooperation than under universal defection-and, second, cooperation appears as a dichotomous variable-either everybody cooperates, or nobody does. In tax competition, by contrast, cooperation is neither mutually beneficial, nor is the relevant choice between global cooperation and global competition, but rather between regional cooperation and no cooperation at all.

To be sure, cooperation theorists did not shun the problem of lack of mutual interest because they missed that it might complicate cooperation. Quite to the contrary, they argued that it would complicate cooperation so much as to make the very notion of cooperation senseless. After all, what does cooperation mean when one country's problem is another country's solution? As Oye remarks, "If at least one actor prefers nominal mutual defection (DD) to nominal mutual cooperation (CC) ... the term 'cooperation' becomes inapplicable."71 Perhaps not quite. The absence of mutual interest does not necessarily imply that there is no potential for mutual gain. In the tax competition game, for example, the aggregate payoff (i.e., the sum of the individual countries' payoffs) improves through cooperation even though the individual payoff of the smaller country deteriorates.

Obviously it could be argued that as long as a lack of mutual interest situation has the potential of being turned into a positive-sum situation through side payments, it is not really a lack of mutual interest situation at all. In the transaction cost free world of the Coase theorem, ${ }^{72}$ this would certainly be true: as long as there is potential for aggregate improvement, all affected actors would have an incentive to be involved in a "grand coalition" of cooperation. In reality, however, side payments are costly, which forces actors to limit cooperation to a subset (" $m$-group") in order to keep intracoalition relations manageable. But this in turn 
creates its own problem, in the form of the outside world constraint. If there are leakage effects, cooperation might not yield enough intracoalition benefit to make the necessary side payments feasible. ${ }^{73}$

Evidently, transactions costs create a dilemma: either actors reduce intracoalition conflict by selectively excluding potential claimants on side payments, but then the outside world constraint becomes more stringent, or they mitigate this constraint by extending the coalition to outsiders, but then any potential gains are eroded by intracoalition transactions costs needed to ensure these gains.

This dilemma is encountered not only in tax competition but also in other fields of regulatory competition, ${ }^{74}$ such as European social policy, where the eleven signatories of the Maastricht Social Protocol have been unable to exploit the reduction in conflict achieved through the exclusion of the United Kingdom because it was feared that any improvement in continental social regulations would have promoted the leakage of foreign direct investment to this outsider. ${ }^{75}$ The problem also appears in other global contexts, such as protection of common environmental resources and other common pool resources. ${ }^{76}$ In short, then, our analysis reintroduces to the study of international cooperation what the neoliberal institutionalism has tended to overlook: absolute loss rather than relative gain. "Now that's politics - pain, coercion, violence-in a word redistribution."77

\section{NOTES}

1. Sven Steinmo, Taxation and Democracy: Swedish, British and American Approaches to Financing the Modern State (New Haven, CT: Yale University Press, 1993), 1.

2. Bruno S. Frey, "Intergovernmental Tax Competition," in Charles McLure, HansVemer Sinn, Richard A. Musgrave, and Klaus Vogel, eds., Influence of Tax Differentials on International Competitiveness (Deventer: Kluwer Law and Taxation Publishers, 1990), 89; see also Jacob A. Frenkel, Assaf Razin, and Efraim Sadka, International Taxation in an Integrated World (Cambridge: MIT Press, 1991), 213-14; Hans-Werner Sinn, "The Selection Principle and Market Failure in Systems Competition," Journal of Public Economics 66 (1997) and references cited therein.

3. Mark Hallerberg, "Tax Competition in Wilhelmine Germany and Its Implications for the European Union,” World Politics 48 (April 1996): 328.

4. E.g., Robert Axelrod, The Evolution of Cooperation (New York: Basic Books, 1984); Robert O. Keohane, After Hegemony: Cooperation and Discord in the World Political Economy (Princeton, NJ: Princeton University Press, 1984); Paul R. Milgrom, Douglass C. North, and Barry R. Weingast, "The Role of Institutions in the Revival of Trade: The Law Merchant, Private Judges, and the Champagne Fairs," Economics and Politics 2 (1990); Geoffrey Garrett and Barry R. Weingast, "Ideas, Interests, and Institutions: Constructing the European Community's Internal Market," in Judith Goldstein and Robert O. Keohane, eds., Ideas and Foreign Policy: Beliefs, Institutions, and Political Change (Ithaca, NY: Cornell University Press, 1993).

5. E.g., Vito Tanzi and A. Lans Bovenberg, "Is There a Need for Harmonizing Capital Income Taxes within EC Countries?" in Horst Siebert, ed., Reforming Capital Income Taxation (Tübingen: Mohr, 1990), 190; David Carey, Jean-Claude Chouraqui, and Robert P. Hagemann, The Future of Capital Income Taxation in a Liberalised Financial Environment, 
Working Paper No. 126 (Paris: OECD Economics Department, 1993), 12-13. See also Financial Times, 23/24 May 1998, 5.

6. Kommission der Europäischen Gemeinschaften, Steuern in der Europäischen Union. SEK(96) 487 endg. (1996), 8.

7. The term tax cooperation could potentially mean many different things. In this paper, we use it in the restricted sense of multilateral action to stop tax competition.

8. We use the terms $E C$ and $E U$ interchangeably, though when referring to the preMaastricht era, we will prefer EC.

9. Geoffrey Garrett, "International Cooperation and Institutional Choice: The European Community's Internal Market," International Organization 46 (Spring 1992): 537.

10. Kenneth Oye, "Explaining Cooperation under Anarchy: Hypotheses and Strategies,” World Politics (Fall 1985): 7.

11. Our model attempts to crystallize the essence of the much more complex models developed in the economics literature; for example, R. Kanbur and M. Keen, "Jeux sans frontières: Tax Competition and Tax Coordination When Countries Differ in Size," American Economic Review 83 (1993).

12. For convenience, we also assume that both countries have access to the same technology. Differences in technology would not qualitatively affect the results.

13. Formally, the decision variables turn out to be homogeneous of degree zero in $\bar{K}$. This means that the logic of the results is unaffected if we allow the world capital stock to grow or shrink.

14. In this simple setting, one could just as easily interpret it as a sales tax on output.

15. This is innocuous. If it were a specific tax, revenue would be a function of $K_{i}$ rather than $F\left(K_{i}\right)$.

16. As a revenue maximizer, it will set a tax rate equal to one. To be sure, this is unrealistic. However, since we are not concerned with taxation in the closed economy but in the strategic effects of tax competition, we exclude domestic sources of distortion that place independent constraints on the ability to tax.

17. In contrast to the usual Laffer curve of public economics, which arises due to the distorting effects of taxation, this Laffer curve is generated solely by tax base mobility.

18. The parameterization used is $\bar{K}=100, \alpha=-0.6, t_{I I}=(0.25,0.5)$, where the solid lines are for the lower value and the dashed lines for the higher value of country $I I$ 's tax rate.

19. Note that the assumption that $F$ is "neoclassical" (i.e., increasing and concave) ensures that this equation has a unique solution, which moreover is positive.

20 . The reaction functions come from equation (11) for country $I$ and a symmetric equation for country $I I$.

21. Note also that the equilibrium is symmetric because of the assumption of identical technologies. We would generally expect asymmetric equilibria if states enter the competition with differing technologies.

22. In other words, the model can explain a "race toward the bottom," but does not find evidence for a "race to the bottom," drawing on a distinction due to John Douglas Wilson, "Capital Mobility and Environmental Standards: Is There a Theoretical Basis for the Race to the Bottom?" in J. Bhagwati and R. Hudec, eds., Fair Trade and Harmonization: Prerequisites for Free Trade? vol. 1 (Cambridge: MIT Press, 1996), 393.

23. Formally, the presence of diminishing returns ensures that each country's reaction curve is upward sloping and convex in the other country's tax rate, implying a unique intersection in the interior of the nonnegative orthant.

24. This is immediate because, whereas it is split differently, the global tax base is constant in all cases. Since tax rates are lower in the strategic case in each country, it follows $a$ fortiori that tax revenue is lower for both countries taken together. 
25. Commission of the European Communities, Taxation in the European Union: Report on the Development of Tax Systems (COM(96) 546 final, 1996), 8.

26. Alberto Giovannini and James R. Hines, Jr., "Capital Flight and Tax Competition: Are There Viable Solutions to Both Problems?" in Alberto Giovannini and Colin Mayer, eds., European Financial Integration (Cambridge, UK: Cambridge University Press, 1991), 172.

27. Council directive 88/361/EC of 8 July 1988 for the implementation of Article 67 of the EC Treaty.

28. Eric Helleiner, States and the Reemergence of Global Finance: From Bretton Woods to the 1990s (Ithaca, NY: Cornell University Press, 1994), 158.

29. Financial Times, 9 February 1989, 2; Financial Times, 14 February 1989, 28; Financial Times, 11 April 1989, 2; Financial Times, 18 April 1989, 3.

30. International Monetary Fund (IMF), International Capital Markets: Developments and Prospect (Washington, D.C.: IMF, 1990), 64.

31. Financial Times, 22 May 1989, 4.

32. Philippe Defeyt, "Tax Structure Harmonization in 1992: The Belgian Perspective," in Georg Winckler, ed., Tax Harmonization and Financial Liberalization in Europe (New York: St. Martin's, 1992), 65.

33. Deutsche Bundesbank, "Aufkommen und ökonomische Auswirkungen des steuerlichen Zinsabschlags,” Monatsbericht (Januar 1994): 49-55.

34. Frankfurter Allgemeine Zeitung, 8 April 1993, 15.

35. Financial Times, 12 July 1994, 3.

36. Kommission der Europäischen Gemeinschaften, Steuern in der Europäischen Union.

37. Agence Europe, 27/28 January 1997, 7.

38. Agence Europe, 3 December 1997, 4-5.

39. Jeffrey Owens, "Globalisation: The Implications for Tax Policies," Fiscal Studies 14 (1993): 33.

40. See Commission of the European Communities, Report of the Committee of Independent Experts on Company Taxation (Ruding Report) (Luxembourg: Office for Official Publications of the EC, 1992), 94 for some methodological obstacles to such a survey.

41. Center for Economic Policy Research (CEPR), Making Sense of Subsidiarity: How Much Centralization for Europe? (London: CEPR, 1993), 69.

42. Deutsche Bundesbank, "Aufkommen."

43. The importance of investment funds for tax evasion purposes has also been observed in other contexts; see, for example, Alberto Giovannini, "National Tax Systems versus the European Capital Market," Economic Policy 9 (1989): 362; Richard M. Levich and Ingo Walter, "Tax-Driven Regulatory Drag: European Financial Centers in the 1990s," in Horst Siebert, ed., Reforming Capital Income Taxation (Tübingen: Mohr, 1990), 86; Edward H. Gardner, "Taxes on Capital Income: A Survey," in George Kopits, ed., Tax Harmonization in the European Community: Policy Issues and Analysis (Washington, D.C.: International Monetary Fund, 1992), 67; Caroline Doggart, Tax Havens and Their Uses 1993 (London: The Economist Intelligence Unit, 1993), 45-50.

44. Deutsche Bundesbank, "Aufkommen," 50-53.

45. The general results would not change if Spain were counted as a "large country."

46. See Owens, "Globalisation," 29.

47. Frankfurter Allgemeine Zeitung, 24 March 1993, 26.

48. Financial Times, 28 March 1996, 3.

49. Konrad Littmann, "Kritisches zur Krise der öffentlichen Finanzen," Staatswissenschaften und Staatspraxis 7, no. 4 (1996): 466. 
50. The analytical importance of this finding should not be overstated. Tax competition is not the only and definitely not the most important determinant of the government debt ratio. However, the political importance of these figures is significant because governments in Germany and France have widely used them to make their case against tax competition.

51. See Stephen D. Krasner, "Global Communications and National Power," World Politics 43 (1991) and Oye, "Explaining Cooperation under Anarchy."

52. Garrett, "International Cooperation and Institutional Choice," 547.

53. Kommission der Europäischen Gemeinschaften, Programm für die Harmonisierung der direkten Steuern. Bulletin der Europäischen Gemeinschaft. Supplement 8/1967, 12.

54. See Council directive 88/361/EC of 8 July 1988 for the implementation of Article 67 of the EC Treaty.

55. Gardner, "Taxes on Capital Income," 68.

56. Roger H. Gordon, Can Capital Income Taxes Survive in Open Economies? Working Paper No. 3416 (Cambridge, MA: National Bureau of Economic Research, 1990), 20, italics added.

57. The membership of the $m$-group is taken as exogenously determined. Endogenizing the group of cooperators raises difficult issues that are still at the frontiers of game theory research. See, for example, Debraj Ray and Rajiv Vora, "Equilibrium Binding Agreements," Journal of Economic Theory 73, no. 1 (1997).

58. The model's behavior is qualitatively the same under alternative parameter specifications.

59. Note also that the simulations reveal that partial cooperation is prone to defection, as suggested by the prisoners' dilemma metaphor.

60. E.g., Jagdish Bhagwati and Arvind Panagariya, "Preferential Trading Areas and Multilateralism: Strangers, Friends, or Foes?" in Jagdish Bhagwati and Arvind Panagariya, eds., The Economics of Preferential Trade Agreements (Washington, D.C.: AEI Press, 1996).

61. See, for example, Kommission der Europäischen Gemeinschaften, Steuerliche Maßnahmen, die Gemeinschaft im Zusammenhang mit der Liberalisierung des Kapitalverkehrs zu treffen hat. Kom (89) 60/3/Revision endg. (1989): 3-4; Gardner, "Taxes on Capital Income," 61.

62. Roger H. Gordon and A. Lans Bovenberg, "International Capital Immobility," American Economic Review 86 (December 1996); Mark Hallerberg and William Roberts Clark, "How Should Political Scientists Measure Capital Mobility? A Review" (paper prepared for the 1997 annual meeting of the American Political Science Association, Washington, D.C., August 28-31, 1997); and the literature reviewed therein.

63. Gordon and Bovenberg, "International Capital Immobility," 1059-60.

64. Martin Feldstein, "Tax Policy and International Capital Flows," Weltwirtschaftliches Archiv 130 (1994): 683.

65. Andreas Haufler, "Perspectives of Corporate Taxation and Taxation of Investment Income," in Austrian Federal Ministery of Finance, ed., Tax Competition and Coordination of Tax Policy in the European Union (Vienna: Austrian Federal Ministry of Finance), 148.

66. Hans-Hagen Härtel et al., Grenzüberschreitende Produktion und Strukturwandel. Globalisierung der deutschen Wirtschaft (Baden-Baden: Nomos, 1996), 340.

67. Gardner, "Taxes on Capital Income," 68.

68. We conjecture that introducing imperfect mobility into our extended model would result in a more steeply rising benefit curve for the cooperators (solid line in Figure 4), 
which might, therefore, intersect the benefit curve for the noncooperators (dashed line in Figure 4). This would imply that there exists a critical $m$-group for which cooperation is beneficial.

69. The classic reference is Richard G. Lipsey and Kelvin J. Lancaster, "The General Theory of the Second Best," Review of Economic Studies 24 (1956-1957). For a recent survey, see Pravin Krishna and Arvind Panagariya, A Unification of the Theory of Second Best, Working Papers in International Economics No. 31, Center for International Economics, Department of Economics (College Park, MD: University of Maryland, 1997).

70. The canonical references include Arthur A. Stein, "Coordination and Collaboration: Regimes in an Anarchic World," International Organization 35 (1982); Duncan Snidal, "Coordination versus Prisoners' Dilemma: Implications for International Cooperation and Regimes," American Political Science Review 79 (1985); Krasner, "Global Communications and National Power"; Garrett and Weingast, "Ideas, Interests, and Institutions." See James D. Fearon, "Bargaining, Enforcement, and International Cooperation," International Organization 52 (1998) for a recent reevaluation of the distinction between coordination and cooperation problems.

71. Oye, "Explaining Cooperation under Anarchy," 6.

72. Ronald H. Coase, "The Problem of Social Cost," Journal of Law and Economics 3 (1960).

73. There is a sophisticated literature on the numbers problem, which analyzes how an increase or decrease in the number of potential cooperators can make cooperation more or less difficult, but there is no analytical appreciation of the fact that the group of potential cooperators is often limited to a subset of the population of relevant states. See, e.g., Duncan Snidal, "The Politics of Scope: Endogenous Actors, Heterogeneity and Institutions," Journal of Theoretical Politics 6 (1994) and literature cited therein.

74. See Philipp Genschel and Thomas Plümper, "Regulatory Competition and International Co-operation," Journal of European Public Policy 4 (1997).

75. Loukas Tsoukalis, The New European Economy Revisited (Oxford, UK: Oxford University Press, 1997), 133. In the meantime, the United Kingdom has entered the Social Protocol, making the problem once again unmanageable intracoalition conflict.

76. Ronald B. Mitchell and Patricia Wolff, "International Environmental Institutions: Symmetry and Sanctions, Asymmetry and Rewards" (paper presented at the Rational International Institutions Conference, University of Chicago, May 1998).

77. Morris P. Fiorina, “Comment: The Problems with PPT," Journal of Law, Economics, and Organization 6 (1990): 256. 